\title{
Bird Haven Par Excellence
}

Florence Brooman, Prince Albert

$\mathrm{NE}^{\mathrm{NE}}$ of the highlights of a trip to the south of the province this summer was a visit to Fred Bard's place on the outskirts of Regina. (Mr. Bard is Director of the Provincial Museum of Natural History). He has five acres along Wascana Creek which is a haven for birds. The grass and reeds are full of nesting ducks, grebes and coots. The sky is background to wheeling terns, darting swallows and flighty sandpipers.

A dugout provides water for irrigating a large garden full of fruits, vegetables and flowers. Surrounding it is a windbreak of trees and shrubs. There the Brown Thrashers and Cuckoos hide; Clay-coloured Sparrows and Kingbirds nest. In a high box a Starling family is keeping house, and everywhere one looks there is bird life.

Here is a wonderful set-up for studying birds at first hand. Mr. Bard, assisted by Fred Lahrman, is using it to the full by taking photographs and movies of bird activities and by keeping check lists and nesting records.

It is an inspiration to all nature lovers to see such a spot and encourages one to look for a similar place in which to live.

\section{Our Little Clown Of the Bush Arthur Ward}

A GAIN prairie conditions have assisted in the wide distribution of migratory birds. Those habituals, that stay with us to rest, have been sadly lacking again this year. Our usual numbers of Brown Thrashers gave us the go-bye, while the Tyrannus and Arkansas Kingbirds were in full strength. Our dear old jester, the Catbird, was very well represented and gave us the pleasure of its antics. It is a lover of thickets and hatches out from four to six green-blue eggs in a scrap-bag of a nest.

If he eats a little fruit he has our grateful permission as small pay for the destruction of moths. His glorious song, too, is another asset. Truly we would greatly miss our little clown of the bush if he did not show up every spring. He likes to investigate the traps and we present him with a nice bright new band on the left leg, which he displays to us when he returns the following year. We had one of these banded birds return last year and another one this year.

\section{Pelicans}

\section{By Evelyn $M$. Casson}

$O^{N E}$ lovely afternoon late in July I noticed away up in the sky what appeared to be bits of white paper. There were three bits and they sailed in circles as if caught in a slow-motion whirlwind; a flash of white then gone-a flash of white then gone.

As .I watched they came closer and closer and soon I could see the large beaks and the black and white markings of pelicans. The grace and beauty of their flight held me spell bound.

They flew in the form of a triangle, but each describing its own circle. Round and round they went in long graceful sweeps but staying in perfect formation. As I watched them I could almost feel with them their joy of that flight in the beautiful blue.

On they sailed over the house and to the north-back to the shores of Birch Lake and and home.

\section{A Cardinal Visitor}

Mrs. Bert Ford, Hazelcliffe, Sask.

In JANUARY of this year, while visiting in Esterhazy one bright sunny afternoon, I was delighted to see a beautiful specimen of a male Cardinal. Having lived here for almost half a century and having been a bird lover, this was the first Cardinal I have seen. It was feeding on scraps of food put out for chickadees and scemed to favor a lilac hedge around the yard. 